\title{
INVENTÁRIO E REINVENÇÃO DA TRADIÇÃO ORAL EM GUIMARÃES ROSA
}

\author{
Marli Fantini Scarpelli \\ Universidade Federal de Minas Gerais
}

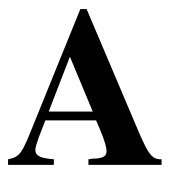

tento ao mapa político contemporâneo, Edward Said observa que a prática nômade, transgressivamente apropriada pela literatura à crescente realidade dos deslocamentos massivos, permite divisar um mapa do mundo sem "nenhum espaço, essência ou privilégio divinamente ou dogmaticamente sancionado". ${ }^{1}$ Ao ampliar os horizontes literários e sócioculturais, esse modelo, flagrado na interseção entre práticas políticas e formações discursivas, encontra similitude com a concepção de Eric Auerbach (1995), segundo o qual "nosso lar filológico é o mundo, e não a nação nem o escritor individual". ${ }^{2}$ Trata-se de tendências finesseculares que podem ser surpreendidas nas fronteiras discursivas de Guimarães Rosa, cuja cartografia verbal salienta a interatividade dialógica entre cenários, temporalidades e identidades sempre móveis, errantes, remanejáveis.

A diversidade de focos decorrente do olhar multifacetado de Rosa é, no meu entendimento, fator interveniente na constituição de sua poética de "fronteiras", por cujas linhas de fuga bordeja toda uma gama de "diferentes": forasteiros, mascates, desterrados, lunáticos, foras-da-lei, frontiers, borders, habitantes das margens, dos subterrâneos, dos brenhais. O imaginário espacializante do escritor mineiro confere materialidade a entre-lugares intersticiais, a zonas fronteiriças, onde trafega toda essa comunidade migrante. É possível surpreender a contínua passagem dos elementos precedentes desse

${ }^{1}$ SAID, 1995. p.383.

${ }^{2}$ SAID, 1995. p.390. 
universo móvel para uma nova configuração lingüística e sóciocultural. A mudança quase imperceptível de uma para outra esfera projeta, nos reversíveis cenários rosianos, um modelo de permuta identitária que desliza das irredutíveis singularidades locais para a amplitude heterotópica do global, dando visibilidade à formação de culturas híbridas, ou de "híbridos culturais", conforme expressão de Stuart Hall. ${ }^{3}$

A viagem por muitas geografias, o convívio com diversas culturas, o conhecimento de várias línguas são indubitáveis fatores a intervir no enfoque fronteiriço privilegiado por Guimarães Rosa em seus cenários discursivos. Ainda que enfoque as singularidades geopolíticas, culturais e lingüísticas do sertão mineiro, o autor de Grande sertão: veredas submete o repertório de suas matrizes regionais arcaicas e endogâmicas à prática simultânea de decomposição e recomposição, podendo, dessa forma, salientar os múltiplos legados culturais que colocam sua Minas Gerais em relação interativa com a herança ibérica e, ao mesmo tempo, com a modernidade ocidental. Essa operação confere aos textos rosianos uma maleabilidade estranha à impermeável dureza com que, via de regra, nossos romances regionalistas se fecham em questões estritamente locais. Explorado na literatura rosiana como signo de heterogeneidade e de mundo, o sertão mineiro, segundo depoimento do próprio escritor, traz, desde a fundação, a marca da hibridez histórica e cultural:

Naturalmente não se deve supor que quase toda a literatura brasileira esteja orientada para o "regionalismo", ou seja, para o sertão ou para a Bahia (...) este pequeno mundo do sertão, este mundo original e cheio de contrastes, é para mim o símbolo, diria mesmo o modelo de meu universo. Assim, o Cordisburgo germânico, fundado por alemães, é o coração do meu império suevo-latino. Creio que essa genealogia haverá de lhe agradar. ${ }^{4}$

${ }^{3}$ HALL, 1999. p.62.

${ }^{4}$ ROSA, 1994. p.31. 


\section{Ato fundacional}

Nas sociedades sem escrita, arquivos ou monumentos, cabe aos especialistas em memória - os "homens-memória" - a função de depositários da memória coletiva. Eles são a memória dessas sociedades, guardiães da tradição em que a história e o mito normalmente se confundem..$^{5} \mathrm{O}$ escasseamento desses "guardiães", em decorrência sobretudo do impacto modernizador, enfraquece a memória coletiva de sociedades arcaicas e põe em risco suas tradições. O resgate da tradição oral de culturas em vias de desaparecimento é uma das mais recorrentes estratégias empregadas na literatura do escritor mineiro. A recuperação da oralidade através da escritura representa, segundo Ana Pizarro, um ato fundacional que cumpre, na perspectiva contemporânea, uma função simbólica de caráter restaurador, que se aproxima à da fundação das cidades. ${ }^{6}$

Depois de inúmeras travessias pelo estrangeiro, seja enquanto embaixador, seja enquanto turista-aprendiz de outras geografias, o escritor João Guimarães Rosa viaja ao interior de Minas Gerais e, procedendo como tradutor-restaurador do próprio domínio cultural e lingüístico, põe-se a tarefa de inventariar, revigorar e reinventar contos, cantos, danças, valores culturais e singularidades lingüísticas de uma tradição oral soterrada por quase 500 anos de encobrimentos.

Uma das mais emblemáticas imagens rosianas é "terceira margem", de cujos interstícios surgem entre-lugares abertos ao intercâmbio entre formações culturais e usos lingüísticos divergentes e muitas vezes irredutíveis uns aos outros. Ao suportar o deslizamento das particula-ridades regionais para a diversidade do universal, os movediços territórios de Rosa dão visibilidade à interface topológica de um sertão-mundo, onde "o interior e o exterior já não podem ser separados". 7 Local e global, arcaico e moderno, hegemonia e

\footnotetext{
${ }^{5}$ LE GOF, 1996. p.428-429.

${ }^{6}$ PIZARRO, 1993. p.26.

${ }^{7}$ Frase de Goethe, citada por Rosa em entrevista por ele concedida a Gunter Lorenz, em ROSA, 1994. p.50.
} 
subalternidade, oralidade e escritura, entremesclados por formações idiomáticas e culturais de diferenciadas procedências, crescem na pele dilatável de uma cartografia móvel e apta, portanto, a comportar a "heterogeneidade multitemporal" 8 que preside ao macro-processo de formação do Brasil e da América Latina.

\section{Pedra das palavras}

Um exemplo do imaginário restaurador de Rosa pode ser vislumbrado na novela "O recado do morro", 9 onde as palavras da terra, grito e canto territorial, desencadeiam "um acontecimento microscópico [que] estremece o equilíbrio do poder local," ${ }^{10}$ despertando as vozes silenciadas de seres periféricos esquecidos da história. São proto-homens, lunáticos, fanáticos, marginais da razão, desentocando-se de suas grutas, grotas e brenhais, à passagem de uma excursão científica, comandada por seo Olquist (ou Alquist), um naturalista alemão. Este excursiona por sítios arqueológicos da "Lundiana ou Lundlândia" ( $R M$, p.11) - região mineira de grutas, localizada no entorno de Cordisburgo e Morro da Garça - para revisitar o objeto das pesquisas palenteológicas realizadas, no século XIX, pelo naturalista dinamarquês, Peter Lund.

Imiscuindo-se na comitiva, os seres ex-cêntricos da região acabam por desestabilizar a trajetória do cientista, provocando-lhe direção e sentido imprevistos. O próprio guia da expedição, Pedro Orósio, é um enxadeiro que, não sendo do local e desconhecendo-lhe a topografia, não sabe guiar e é, portanto, um dos responsáveis pela dissolução do grupo e pela mudança dos objetivos da "viagem", cujo percurso já é, desde seu início, vetorizado por referências móveis:

\footnotetext{
${ }^{8}$ CANCLINI, 1995. p.72.

9 ROSA, 1969. Doravante, a referência à novela "O recado do morro" será feita no corpo do texto sob a sigla $R M$, seguida da respectiva página.
}

${ }^{10}$ DELEUZE; GUATTARI, 1995. p.25. 
E seguiam, de um ponto a um ponto, por brancas estradas calcáreas, como por uma linha vã, uma linha geodésica. Mais ou menos como a gente vive. Lugares. Ali, o caminho esfola em espiral uma laranja: ou é a trilha escalando contornadamente o morro, como um laço jogado em animal $(R M, 13)$.

A passagem da comitiva pelo local de uma cultura arcaica prestes ao apagamento causa abalos sísmicos no morro da Garça, de cujas entranhas irrompe um alerta, sob a forma de bramido da terra. Essa irrupção é apreendida pelo Gorgulho, um marginal da razão, que a toma por um vaticínio do fim trágico de Pedro Orósio, o guia da expedição: "- "H'hum... Que é que o morro não tem preceito de estar gritando... Avisando as coisas... (...) Morte à traição, foi o que ele Morro disse"” ( $R M, 15 ; 22)$. O emissário da voz territorial é "um criaturo ananho", alucinado, meio surdo, a cuja fala truncada, ninguém, a não ser o alemão-rana dá ouvidos. Este, pelos ruídos significantes da mensagem, intui-lhe a importância, e, enquanto estrangeiro, procede como tradutor da estranheza da língua cujos próprios usuários se mostram incapazes de reconhecer: “- "Hom' est' diz xôiz' immportant!» - ele falou brumbrum. Só se pelo acalor de voz de Gorgulho ele pressentia. E até deu apressadas frases ao Gorgulho, naquela língua sem as possibilidades" ( $R M, 22)$.

À medida, no entanto, que vai sendo retransmitido pelo circuito dissonante e dialógico de sete "marginais da razão", o recado do morro, como um canto coral já desterritorializado, desemboca numa saga heterofônica para uma terra sem mapa. Pela arte de Laudelim Pulgapé, um bardo popular, o recado converte-se finalmente numa "cantiga migradora", que carrega, no modo de intencionar sua própria constituição, os signos desencadeadores da transmissibilidade e traduzibilidade implicadas no processo de preservação e difusão da tradição oral.

Comovido, ele [seo Alquist] pressentia que estava assistindo ao nascimento de uma dessas cantigas migradoras, que pousam no coração do povo: que as violas semeiam e os cegos vendem pelas estradas. - "Importante... Importante..." - afirmava o senhor Alquist, sisudo subitamente, desejando que lhe traduzissem o texto, digestim 
ac districtim, para o anotar. Sem apreender embora o inteiro sentido, de fora aquele pudera perceber o profundo do bafo, da força melodiã e do sobressalto que o verso transmuz da pedra das palavras (...) o senhor Alquist queria comentar muito, em inglês ou francês, ou mesmo em seus cacos de português, quando não se ajudando com termos em grego ou latim. - "Digno! Digno! Como na saga de Hrolf filho de Helgi (...)". Referia: - "Ah, está em Saxo Grammaticus!" ( $R M, 64)$.

Porque descolado das questões locais, além de apreender e traduzir a voz do oráculo regional, o viajante estrangeiro é, dentre todos quantos testemunharam o nascimento do canto territorial, o único capaz de reconhecer-lhe, nas peculiaridades locais, o índice do universal. Imbricando e superpondo todo um universo de conflitantes heterogeneidades em curso, essa espacialidade móvel que comporta presença e ausência de línguas, culturas, saberes que, fora dali, seriam irredutíveis uns aos outros, faz emergir uma terceira margem, zona de tensões onde todas as vozes, embora preservando suas próprias entonações, mesclam-se sob a disposição de negociar suas diferenças. Negociação sempre em curso a reduzir as polaridades num grau tão concentrado de fatura poética, lingüística e cultural, que irá engendrar esta impactante descoberta do narrador: "Outros eram os outros" $(R M, 10)$. Frente, enfim, à fratura do sentido teleológico que dá suporte ao caráter científico da excursão, os atores culturais que dela, direta ou indiretamente, participam vêm-se obrigados a permutar seus papéis. De fato, em face do crescente esvaziamento de um sentido e um fim determinados, desencadeiase o processo de inter-relação desierarquizada entre o saber epistemológico do viajante europeu e o saber mitopoético dos habitantes das margens, o que possibilita o resgate de 500 anos de tradição oral preservada subterraneamente à margem da história oficial.

Assim, a partir do inusitado intercâmbio entre "três patrões, entrajados e de limpo aspecto, pessoa de pessoa" (...) pessoas instruídas, gente de mando" ( $R M, 5 ; 10)$ e o grupo de apoio que conduz a comitiva, "debaixo de ordem" ( $R M, 5)$, ou seja, entre o hegemônico e o subalterno, o hermenêutico e o grotesco, minimaliza-se a distância entre o mesmo e o outro, o que culminará na inter-relação de 
conhecimentos diferenciados e na criação coletiva da "cantiga migradora". O grande contributo desse processo é a negociação produtiva entre alteridades de início inconciliáveis. Ao legitimar-se o pensamento "selvagem", a autoridade do saber epistemológico desierarquiza-se, abrindo espaço para o intercâmbio de culturas de prestígio diferenciado, para identidades compartilhadas. A negociação entre imaginários distintos ocorre sob a mediação da "hermenêutica heterotópica" ${ }^{11}$ com que, depois do "recado", a perspectiva do viajante europeu passa a operar. Ao buscar um sistema explicativo para apreender a mirada mitopoética do "outro", aquele vê-se obrigado a equacionar a perspectiva eurocêntrica que endossa seu conhecimento "formal". Dessa forma, torna-se-lhe possível verificar que, embora com meios diferentes, o saber intuitivo, "não-formal" não só possui operadores para realizar sua própria leitura de mundo, mas também se mostra produtivo no sentido de suplementar e potencializar o conhecimento científico.

Qual é, afinal, o recado do morro? O que o morro manda dizer? Sob a forma de um "ritornelo", ${ }^{12}$ canto da terra para um coro polifônico, o recado da novela desloca-se, graças à produtiva mediação da perspectiva estrangeira, do âmbito local para o universal, a fim de gritar seu alerta contra a letargia de um Brasil deitado eternamente em berço esplêndido. Causar abalo em camadas arqueológicas que ocultam histórias recalcadas, pôr em relevo e circulação vozes silenciadas pelo poder local, restaurar um sentido que ninguém mais é ouve, esse é o recado de um Brasil periférico, cujo grito irrompe das dobras do mapa oficial.

\footnotetext{
11 Walter Mignolo (Apud Pizarro, 1993) designa como "hermenêutica heterotópica”, o paradigma mediante o qual se pode compreender o modo como os membros de cada cultura pensam as práticas culturais e discursivas do outro. MIGNOLO, 1993. p.531.

12 Sobre "ritornelo", ver DELEUZE; GUATTARI, 1995. p.8-9.
} 


\section{O legado da tradição oral}

Dentre outros textos rosianos, também a meta-novela "Carade-Bronze" ficcionaliza o processo coletivo que rege a constituição da rede da oralidade. O protagonista da novela, encarregado da tarefa de buscar o "quem das coisas", vê-se incessantemente obrigado a operar como um tradutor e, dessa forma, a suplementar o escorregadio objeto de sua demanda, basicamente constituído de narrativas que formam o acervo da tradição oral. ${ }^{13}$

Ao problematizar algumas formas de transmissão da memória, Eneida Maria de Souza endossa o pensamento de Paul Zumthor (Apud Souza, 1999), segundo o qual uma das propriedades do texto oral é a perda dos traços autorais. Isso se dá em vista de a transmissão passar por uma cadeia de intermediários, e o conhecimento da mensagem advir da versão de seu último transmissor: "Esse intérprete, contudo, ao reclamar para si a autoridade enquanto intérprete, consegue atenuar a idéia de serem essas composições marcadas pelo anonimato". ${ }^{14}$ Em "Cara-de-Bronze", contudo, ao constituir-se a partir da intervenção de várias vozes anônimas, o acervo das narrativas coletivas dilui a noção de propriedade autoral. Isso se deve, sobretudo, ao entrecruzamento de várias vozes na rede da tradição oral, que, uma vez sujeito a um proliferante comércio simbólico, transforma a mensagem em um bem coletivo.

"Cara-de-Bronze", personagem da novela homônima, é um fazendeiro desterrado de sua "pátria arquetípica". Idoso, doente e "sem elixir" $(C B, 99)$ que lhe minimize a melancolia, ele escolhe o Grivo, um vaqueiro-poeta, para recuperar as estórias confinadas em sua região de origem, onde ele viveu até mudar-se, ainda jovem, para o Urubùquaquá. Dentre os quarenta vaqueiros que ele entrevistou, o Grivo é o que lhe parece mais dotado do potencial poético necessário

${ }^{13}$ ROSA, 1969. Doravante a referência à novela "Cara-de-Bronze" será feita no corpo do texto sob a sigla $C B$, seguida da respectiva página.

${ }^{14}$ SOUZA, 1999. p.142. 
à tarefa de apreender, restaurar e difundir "o quem das coisas!" ( $C B$, 101). O leitmotiv da novela é assim resumido por Guimarães Rosa:

O «Cara-de-Bronze» era do Maranhão (os campos gerais, paisagem e formação geográfica típica, vão de Minas Gerais até lá, ininterruptamente). Mocinho, fugira de lá, pensando que tivesse matado o pai etc. Veio, fixou-se, concentrou-se na ambição e no trabalho, poderoso e rico. Triste, fechado, exilado, imobilizado pela paralisia (que é a exteriorização de uma como que "paralisia da alma"), parece misterioso, e é; porém, seu coração, na última velhice, estalava. Então, sem se explicar, examinou seus vaqueiros - para ver qual teria mais viva e "apreensora" sensibilidade para captar a poesia de paisagens e lugares. E mandou-o à sua terra, para, depois, poder ouvir dele, trazidas por ele, por esse especialíssimo intermediário, todas as belezas e poesias de lá. O Cara-de-Bronze, pois, mandou o Grivo.... buscar poesia. ${ }^{15}$

Incapazes de compreender a natureza dessa negociação, os vaqueiros criam uma nuvem de especulações em torno do sentido da viagem, bem como do mistério que cerca Cara-de-Bronze. A luta contra a falta de sentido gera hipóteses e interpretações, fazendo emergir uma grande rede discursiva, onde se entrecruzam criação, tradução e transcriação do motivo da "demanda".

O vaqueiro Cicica: Estúrdio assim de especular... Que mal pergunte: o senhor, por acaso está procurando por achar alguém, algum certo homem?

Moimeichêgo: Amigo, cada um está sempre procurando todas as pessoas deste mundo.

O vaqueiro Adino: É engraçado... O que o senhor está dizendo é engraçado; até, se duvidar, parece no entom desses assuntos de Carade-Bronze fazendo encomenda dele aos rapazes, ao Grivo...

Moimeichêgo: Que assuntos são esses?

O vaqueiro Adino: É dilatado p'ra se relatar...

O vaqueiro Cicica: Mariposices... Assunto de remondiolas.

O vaqueiro José Uéua: Imaginamento. Toda qualidade de imaginamento, de alto a alto... Divergir na diferença similhante (...).

${ }^{15}$ BIZZARRI, 1981. p.59-60. 
O vaqueiro José Uéua: No coração a gente tem é coisas igual ao que nem nunca em mão não se pode ter pertencente: as nuvens, as estrelas, as pessoas que já morreram, a beleza da cara das mulheres... A gente tem de ir é feito um burrinho que fareja as neblinas? $(C B, 86)$.

Enquanto no "Urubùquaquá" se desenvolvem conjecturas poético-filosóficas em torno da "demanda", o Grivo realiza sua viagem pelos confins dos "Gerais" aprendendo, conforme instrução de seu mestre, a "ver o que no comum não se vê: essas coisas de que ninguém não faz conta" $(C B, 105)$. O uso de signos comerciais, a exemplo da expressão "faz conta", introduz a idéia de permuta na esfera do coletivo. Entretanto, ao pôr em circulação os bens já reciclados, a moeda empregada nesse comércio revela uma outra face: o investimento em trocas discursivas e culturais cujo ganho será compartilhado por todos. A metáfora é evidente: trata-se da intercambialidade de várias vozes agenciadoras da cadeia da oralidade que, em culturas arcaicas, constitui o mais importante mecanismo de preservação, renovação e transmissão de conhecimentos e valores.

Em sua tese sobre o narrador, Walter Benjamin (1987) postula que, ao tecer a rede que todas as histórias constituem entre si, a "reminiscência" - atributo do narrador oral - "funda a cadeia da tradição, que transmite os acontecimentos de geração a geração". ${ }^{16}$ O narrador emblematizado por Benjamin é um homem que sabe aconselhar, e sua sabedoria se manifesta no momento em que ele consegue transmitir experiências: "Aconselhar é menos responder a uma pergunta que fazer uma sugestão sobre a continuação de uma história que está sendo narrada". ${ }^{17}$ A fonte das grandes narrativas arcaicas é, segundo Benjamin, a vivência do narrador, a qual se transforma em saber transmissível no momento de sua (dele) morte: "A morte é a sanção de tudo o que o narrador pode contar. É da morte que ele deriva sua autoridade". ${ }^{18}$

${ }^{16}$ BENJAMIN, 1987. p.211.

${ }^{17}$ BENJAMIN, 1987. p.200.

${ }^{18}$ BENJAMIN, 1987. p.208-209. 
Quando decide legar ao Grivo toda uma tradição arcaica de que é depositário, o agonizante Cara-de-Bronze está tentando preservar e difundir um conhecimento que, doutra forma, estaria condenado ao desaparecimento. De fato, não somente as viagens do Grivo, mas as conversações sobre o entorno dessa viagem revigoram e renovam esse conhecimento. Durante suas idas-evindas, o especialíssimo embaixador do comércio simbólico desencadeado pela "demanda" vai inventariando uma infinita gama de valores, saberes, singularidades culturais e lingüisticas que ele, enquanto tradutor e transmissor, põe em nova circulação.

Entre a restauração e a renovação do "quem das coisas", produzse, entretanto, uma nova rede discursiva, cuja abrangência só a cartografia do virtual tem a capacidade de acompanhar. Os territórios e culturas revisitados com vistas à apreensão da "poesia" crescem, deslocam-se e pluralizam-se a cada novo deslocamento do caminhante solitário. "Estes silêncios estão cheios de outras músicas" ( $C B$, 116) - fala o vaqueiro-poeta acerca das potencialidades encerradas nos entre-lugares os quais, à revelia de sua missão, avolumam-se para ocupar espaços lacunares e embrionários de "regiões ainda por vir". ${ }^{19}$

Assim, há, no périplo poético do Grivo, o impulso para outros lugares, uma outra viagem que incessantemente se desvia da rota prevista. Uma linha se dobrando, se desdobrando e alterando o traçado do mapa, cujos limites não é mais possível controlar. A deambulação pelo sem-fim dos "gerais" resulta numa cartografia errante, feita de "espaços sem lugares, tempo sem duração", conforme expressão de Althusser (Apud Bhabha, 1998) ${ }^{20}$ De fato, à medida que a procura da poesia produz deslocamentos, surge, dos "gerais" em ruína, uma Waste land em cuja conformação espaçada desenhase o mapa de um espaço-linguagem vocacionado para a metamorfose, o fracionamento, a recursividade.

\footnotetext{
${ }^{19}$ DELEUZE; GUATTARI, 1995. p.13.

${ }^{20}$ BHABHA, 1998. p.202.
} 
Forma discursiva desdobrável, o ato insurgente de tradução lingüística e cultural, ao materializar-se na superposição de diferentes planos, além de deflagrar novas trocas simbólicas, renova o passado, reconfigurando-o como um entre-lugar contingente e liminar. O mais importante desse ato de tradução cultural é o fato de provocar, em consonância com esta reflexão de Homi Bhabha, "a emergência de uma narrativa nacional hỉbrida que transforma o passado nostálgico num "anterior" disruptivo e desloca o presente histórico - abrindoo para outras histórias e assuntos narrativos incomensuráveis". ${ }^{21}$

Para fisgar a poesia, o Grivo joga "a rede que não tem fios" $(C B, 126)$, mas descobre que, ao lançá-la, tudo já se "contraverte". Como "pessoa que tivesse morrido de certo modo e tornado a viver" $(C B, 123)$, ele experimenta a aventura da subjetivação. Enquanto Cara-de-Bronze viaja vicariamente "assim mesmo sem sair do quarto" $(C B, 85)$, a viagem do Grivo, passando pelo circuito coletivo, torna-se outra: "Eu quero a viagem dessa viagem..." $(C B, 126)$. Seguindo o mesmo vetor recursivo, o campo discursivo da novela desdobra-se, vertendo-se e revertendo-se para culminar em zonas de convívio entre as mais distintas vozes.

Como se pôde verificar, o Grivo é, inicialmente identificado como o autor da mensagem poética que, na verdade, lhe coube traduzir e difundir. Entretanto, quando os fios da rede narrativa se entremesclam para incluir todo um mosaico de vozes anônimas, a propriedade autoral desaparece, e a mensagem se transforma em um bem coletivo. É assim que, na trama de várias camadas discursivas, o conto representa as trocas simbólicas e culturais agenciadoras da cadeia intersubjetiva da tradição oral.

${ }^{21}$ BHABHA, 1998. p.235. 


\section{Tão longe, tão perto}

A par de toda essa rede interativa, há uma voz sub-reptícia irrompendo da escritura a tentar corrigir, mediante o emprego de estratégias discursivas convencionais, o curso desviante do relato. A despeito desse empenho, a performance verbal sanciona o fluxo poético, deixando desterritorializados sujeito e objeto da enunciação. Consciente da efemeridade dos eventos narrados, dos limites do próprio código e da autonomia da agência narrativa, o narrador da novela adota dois recursos com que experiementa restaurar o "desvio": uma montagem cinematográfica e uma exposição metapoética. Dessa forma, ele se debate, num supremo esforço intersemiótico, contra as irrefreáveis virtualidades desse texto desdobrável e contra a crescente autonomia da narrativa que ameaça expulsar, da rede que tece a tradição oral, sujeito e objeto da escrita.

De fato, ao operar com o recurso da "montagem cinematográfica”, o narrador tenta fixar a realidade permeável e efêmera, refratária, portanto, à imobilização e à representação "clássica". A tentativa de obtenção da imagem-síntese da novela é a alternativa para antecipar e, portanto, controlar, com uma pequena margem de risco, o modo de estruturação, o desenvolvimento e o desenlace da novela. ${ }^{22}$ Se, por um lado, esse recurso permite suspender o tempo (para sintetizar e imobilizar a imagem), por outro, dá-se à imagem uma falsa aparência, visto, dessa forma, ela se deixar assinalar pelo excesso de artificialismo e ficar privada do movimento, que consiste em seu caráter mais autêntico, como se pode ver neste recorte da "montagem cinematográfica" realizada por um diretor de cena em of:

${ }^{22}$ O recurso à montagem cinematográfica tem, segundo Deleuze, "a propriedade de "tornar o presente passado", de transformar nosso presente instável e incerto em "um passado claro, estável, descritível", em suma, de realizar o tempo (...) como representação indireta que decorre da síntese das imagens". DELEUZE, 1990. p.49. 


\section{Roteiro:}

Interior - Na coberta - Alta manhã

\section{G. P. G. Int. coberta}

Entrada dos vaqueiros. Curto prazo de saudações ad libitum, os chegados despindo suas croças - bem trançadas, trespassadas adiante e reforçadas por um cabeção ou "sobrepeliz" sobre os ombros, também de palha de buriti

Linhô Ti entra no plano, de costas

Linhô Ti saúda os vaqueiros recém-vindos.

2 P. A. Int. Coberta. O vaqueiro Mainarte guarda na orelha o cigarro apagado. Apo nta, na direção da varanda, e fez menção de sair.....

Em P. E. M. da câmera, em lento avanço, enquadramse: os currais, o terreiro, a Casa, a escada, a varanda. (...)

Grande plano: Todos riem. Todos comem
Quadros de filmagem: Quadros de montagem: Metragem:

Minutagem:

Som: o violeiro estará tocando uma mazurca

Som: o fim da mazurca

Som: Touros, de curral para curral, arruam o berro tosido, de u-hu-hã , de desafio.

(O touro involuntário, que tem o movimento mau das tempestades.)

O vaqueiro Mainarte: Pedir a ele para cantar cantigas de olêolá, uma cantiga de se fechar os olhos.....

( $C B$, p.92-96)

Na verdade, a dupla operação de abolir o tempo e de reterritorializar o espaço, realizada no sentido de salvar, da efemeridade e da dissolução, "o quem das coisas" e sua arqui-imagem, fracassa tanto na estrutura sistêmica da novela, como em seu making of, já que este não faz senão repetir, em escala menor, aquilo que está sendo experimentado, sem sucesso, no "grande plano" narrativo. Ao passo que a 
intervenção do narrador no curso da agência narrativa seja autoritária, artificiosa e inoperante, quanto maior seu esforço em domar o texto, mais se manifesta sua não-precedência em relação ao curso dos acontecimentos. Em face dessa irredutível evidência, ele interpõe ao relato um tratado metapoético, para discorrer sobre esse livre fluxo.

Enquanto ocupado em justificar a própria impotência frente à potência verbal, o narrador é, sem o perceber, contagiado por outras vozes e circuitos. Assim, só lhe resta tempo para recuperar o fôlego... e não ser eliminado pelo disparo poético que ganha velocidade a partir do meio dessa narrativa sem começo nem fim. A passagem auto-explicativa que segue abaixo expõe o esforço meta-poético do narrador em desvendar o modo de intencionar desta rede de sentidos que, propulsionada por trocas intersubjetivas, ultrapassa os limites de seu (dele) campo discursivo.

Não. Aqui uma pausa. Eu sei que esta narração é muito, muito ruim para se contar e se ouvir, dificultosa; difícil: como burro no arenoso. Alguns dela vão não gostar, quereriam chegar depressa a um final. Mas - também a gente vive somente espreitando e querendo que chegue o termo da morte? Os que saem logo por um fim, nunca chegam no Riacho do Vento. Eles, não animo ninguém nesse engano; esses podem, e é melhor, dar volta para trás. Esta estória se segue é olhando mais longe. Mais longe do que o fim; mais perto (...) Estória custosa, que não tem nome; dessarte, destarte. Será que nem bicho larvim, que já está comendo a fruta, e perfura indo para seu centro. Mas, como na adivinha - só se pode entrar no mato é até ao meio dele. Assim, esta estória ( $C B, 96-7)$.

Da mesma forma que o narrador, o protagonista da novela fracassa e acerta em sua tarefa tradutória. Fracassa por não transplantar "o quem das coisas" em sua forma "primordial". Acerta, paradoxalmente, por essa mesma razão: ao perverter o circuito visado, ele abre o transducto por meio do qual as palavras e as coisas primeiro se permeabilizam e se libertam do lugar comum, escapando, em seguida, por linhas de fuga, em direção ao devir. Assim, as estórias e a brotação poética, que vão interferindo no percurso do Grivo bem como no campo enunciativo, aceitam a alegre relatividade do fluxo que 
caminha a contrapelo do peso morto da história e do indiferente continuum homogêneo e vazio. O lado bem sucedido do "fracasso" é a convergência de vários espaços num mesmo cenário, de vários tempos n'"um tempo saturado de "agoras", ${ }^{23}$ a colidir com o imobilismo acrítico do passado.

Um novo fato estético figura nessa liminaridade espácio-temporal: uma arqueologia da superfície, sempre cambiante, fracionária e provisória. Ainda que inicialmente mobilizada para a empresa metafísica de resgate do "quem das coisas" e comprometida, portanto, com o dogmatismo da única verdade e das formas inteiras, ao romper com o projeto de restauração dos elementos locais perdidos, essa estética aceita a interferência da agência discursiva. Nessa abertura, pode-se reconhecer a emergência de um novo circuito espácio-temporal. A cada reengendramento do roteiro "original", o Grivo descobre viagens dentro da viagem inaugural, por meio das quais pode recartografar o mapa do percurso e, dessa forma, consagrar o redimensionamento da região.

A migração do "regionalismo restritivo" ao "regionalismo de liberação", do nacionalismo ao transnacionalismo amplia, na novela, o horizonte de expectativa espacial e cede lugar ao que Carlos Espartaco (s.d.) chama de "indeterminação universal de lugar". ${ }^{24}$ A especificidade desse novo paradigma espacial reside na sua capacidade de produzir "focos enunciativos autopoiéticos". ${ }^{25}$ Em outras palavras, focos de recursividade, a partir dos quais, a cada errância entre regiões ou a cada reinserção de valores estranhos ao local da cultura, deflagram-se processos de subjetivação, intersubjetividade e reterritorialização.

${ }^{23}$ BENJAMIN, 1987. p.229.

${ }^{24}$ Sobre "regionalismo de restrição" e "regionalismo de liberação", ver ESPARTACO, 1998. p.93-94.

${ }^{25}$ GUATTARI, Félix. Novos paradigmas, cultura e subjetividade, p.127. 
Agenciadores de inesperadas formações discursivas, esses focos colocam, na rede de trocas simbólicas, o grande coro de vozes dissonantes e dialógicas que estavam fora do circuito poético. Ao redimensionar uma geografia pré-estabelecida, o protagonista - de início apenas o emissário encarregado de resgatar a palavra do outro - irá operar sob o mesmo eixo recursivo que vetoriza a história de culturas arcaicas. Em outras palavras, ao acrescentar seu ponto de vista ao "quem das coisas" que lhe foi encomendado, ele acaba por transcriá-lo, interferindo, dessa forma, na rede da tradição oral. Como se sabe, quem desloca um ponto reinventa os contos.

É assim que a novela, ao permeabilizar o mapa das regiões, não somente abre os elos da cadeia da tradição oral para a inserção de vozes silenciadas pela história oficial, como pode preservar e atualizar o circuito dessa tradição. O texto se encerra com a fala de um rude vaqueiro - o vaqueiro Mainarte - da qual emerge, inesperado, o mote desencadeador de uma nova rede de sentidos, portanto uma nova história: "Estou escutando a sêde do gado" $(C B, 127)$.

\section{Identidades partilhadas}

Stuart Hall (1999) trata de um falso dilema, gerado pela emergência de identidades culturais que, sem fixidez, vêm-se obrigadas a retirar seus recursos de diferentes tradições culturais. Produto de complexos e múltiplos cruzamentos culturais cada vez mais comuns no mundo globalizado, as pessoas que atravessaram as fronteiras naturais e foram dispersadas para sempre de sua terra natal, embora mantendo fortes vínculos com as tradições de seus lugares de origem, perderam a ilusão de um retorno a seu passado. ${ }^{26}$ Vêem-se, portanto, obrigadas a conviver com novas culturas, sem ser, contudo, assimiladas por elas. Trata-se de pessoas que, segundo

${ }^{26}$ HALL, 1999. p.88. 
Hall, "devem aprender a habitar, no mínimo, duas identidades, a falar duas linguagens culturais, a traduzir e a negociar entre elas". ${ }^{27}$

As culturas híbridas produzidas pela modernidade tardia constituem, de acordo com as premissas de Hall, esse novo tipo de identidade "partilhada". Mesmo que as pessoas carreguem os traços das culturas, das tradições, das linguagens e das histórias pelas quais foram marcadas, nunca serão unificadas, uma vez que se tornam o produto de várias histórias e culturas interconectadas. Cabe-lhes, portanto, aceitar a evidência de que pertencem a várias casas ou a várias regiões. Para a superação desse dilema, Hall (1999) sugere a alternativa da tradução.

As pessoas pertencentes a essas culturas híbridas têm sido obrigadas a renunciar ao sonho ou à ambição de redescobrir qualquer tipo de pureza cultural "perdida" ou de absolutismo étnico. Elas estão irrevogavelmente traduzidas. A palavra "tradução", observa Salman Rushdie, "vem, etimologicamente, do latim, significando "transferir"; "transportar entre fronteiras". Escritores migrantes, como ele, que pertencem a dois mundos ao mesmo tempo, "tendo sido transportados através do mundo... são homens traduzidos" (Rushdie, 1991. Apud Bhabha, 1998). ${ }^{28}$

Esse processo tradutório é ficcionalizado na novela "Cara-deBronze", cuja personagem homônima, no afã de recuperar suas raízes, encomenda ao Grivo a tarefa de transportar de uma cultura para outra o "quem das coisas" imaginariamente preservado em sua forma original. Procedendo, entretanto, como um tradutor, o emissário, ao transportar o objeto visado através de várias fronteiras discursivas, perde o controle sobre o imaginário da tradição que lhe cabe ressimbolizar. Transplantada para outros domínios, a suposta "pureza" perdida sofre o efeito da desierarquização dos absolutos e se transforma em uma realidade traduzida. A emergência da mescla lingüística, cultural e territorial, implicada nessa operação, redimensiona a noção

${ }^{27}$ HALL, 1999. p.89.

${ }^{28}$ HALL, 1999. p.89. 
de "pureza", "verdade" e "origem", contribuindo para se entender a desterritorialização não como perda, mas como forma permeável e produtiva de trocas simbólicas e de intercâmbio cultural.

A dissolução da propriedade autoral abre, na novela de Guimarães Rosa, fronteiras para a emergência de um espaço móvel e compartilhado. As trocas simbólicas realizadas no espaço escrito da obra literária contribuem para a reflexão sobre as trocas culturais envolvidas no evidente processo de transculturação ${ }^{29}$ realizado a partir do entrecruzamento de vozes anônimas e coletivas, voltadas para o interesse comum em preservar a heterogeneidade diferencial que permeia a inter-relação de distintas culturas. Trata-se de culturas e saberes dialógicos e remanejáveis, continuamente formados e transformados na interação entre a subjetivação e a intersubjetividade e a culminar naquilo que Hall chama de "identidades partilhadas". ${ }^{30}$

Como seu personagem "Cara-de-Bronze", que viaja sem sair do quarto, o escritor mineiro, a partir de seu efetivo trânsito por inumeráveis países e línguas, aprendeu a deslocar-se por diferentes temporalidades, línguas, culturas e geografias, sem precisar sair de sua escrivaninha. Ou, como o naturalista estrangeiro de "O recado do morro", cuja presença no interior mineiro põe em circulação o que estava estagnado, o escritor-diplomata pode derrubar as inumeráveis barreiras a isolar o sertão em relação ao mundo e reajustá-las à forma de um mapa migrante que, aceitando a intervenção de negociações e acaso, mostra-se apto a entrecruzar

${ }^{29}$ Fernando Ortiz entende "o vocábulo transculturação expressa melhor as diferentes fases do processo transitivo de uma cultura a outra, porque este não consiste somente em adquirir uma cultura, que em rigor indica a voz anglo-americana aculturação, mas sim que o processo também implica necessariamente a perda ou desenraizamento de uma cultura precedente, o que poderia dizer-se uma parcial desculturação, e, ademais, significa a conseqüente criação de novos fenômenos culturais que poderiam chamar-se neoculturação." Apud RAMA, 1989. p.32-33. Tradução minha.

${ }^{30}$ HALL, 1999. p.74. 
diferentes territórios e a permeabilizar suas fronteiras. Diferentemente de demarcações identitárias fixas e de cartografias referenciais, o espaço heterotópico dos cenários rosianos cria zonas de confluência, onde se institui um intenso contrabando entre línguas e culturas de diferentes procedências e temporalidades. Essa remarcação discursiva dá visibilidade a identidades em curso, a pátrias itinerantes em permanente confronto e negociação, de onde emerge uma nova forma de habitar o mundo.

\section{Referências Bibliográficas}

BENJAMIN, Walter. Magia e técnica, arte e politica. São Paulo: Brasiliense, 1987. O narrador: considerações sobre a obra de Nikolai Leskov; Sobre o conceito de história.

BIZZARRI, Edoardo. J. Guimarães Rosa: correspondência com seu tradutor italiano Edoardo Bizzarri. São Paulo: T. A. Queiroz Editor, 1981.

BHABHA, Homi K. O local da cultura. Trad. Myriam Ávila et al. Belo Horizonte: Editora UFMG, 1998. DissemiNação; Locais da cultura; O Pós-Colonial e o Pós-Moderno.

CANCLINI, Nestor Garcia. Culturas híbridas: estrategias para entrar y salir de la modernidad. Buenos Aires: Editorial Sudamericana, 1995. CANCLINI, Nestor Garcia.

DELEUZE, Gilles; GUATTARI, Félix. Mil platôs: capitalismo e esquizofrenia. 5v. Trad. Aurélio G. Neto e Célia P. Costa. Rio Janeiro: Editora 34, 1995. v. I.

DELEUZE, Gilles. A imagem-tempo. Trad. Eloisa de Araujo Ribeiro. São Paulo: Brasiliense, 1990.

ESPARTACO, Carlos. Estetico provisorio. Buenos Aires: Fundación Federico Jorge Kemmm Editora, 1998.

GUATTARI, Félix. O novo paradigma estético. In: SCHNITMAN, Dora Fried (Org.). Novos paradigmas, cultura e subjetividade. Trad. Jussara H. Rodrigues. Porto Alegre: Artes Médicas, 1996. 
HALL, Stuart. A identidade cultural na pós-modernidade. Trad. Thomaz T. da Silva e Guacira Lopes Louro. Rio de Janeiro: DP\&A Editora, 1999. O global, o local e o retorno da etnia.

LE GOFF, Jacques. História e memória. Trad. Irene Ferreira, Bernardo Leitão, Suzana F. Borges. Campinas: Editora da Unicamp, 1996.

MIGNOLO, Walter. Palabras pronunciadas con el corazón caliente: teorias del habla, del discurso y de escritura. In: PIZARRO, Ana (Org.). América Latina: palavra, literatura e cultura. São Paulo: Memorial; Campinas: UNICAMP, 1993.

PIZARRO, Ana (Org.). América Latina: palavra, literatura e cultura. São Paulo: Memorial; Campinas: UNICAMP, 1993. Palabra, literatura y cultura en las formaciones discursivas coloniales.

RAMA, Ángel. Tranculturación narrativa en América Latina. Montevideo: Arca Editorial, 1989.

ROSA, João Guimarães. No Urubuquàquá, no Pinbém. Rio de Janeiro: José Olympio, 1969. Cara-de-Bronze. O recado do morro. ROSA, João Guimarães. Guimarães Rosa: ficção completa. 2 V. Rio de Janeiro: Nova Aguilar, 1994. v.1. Diálogo com Guimarães Rosa. SAID, Edward W. Cultura e imperialismo. Trad. Denise Bottman. São Paulo: Companhia das Letras, 1995.

SOUZA, Eneida Maria de. A pedra mágica do discurso. Belo Horizonte: Editora UFMG, 1999. 


\section{Resumo}

Entre uma tradição oral que gradativamente perde sua visibilidade e a dificultosa construção de uma tradição escrita em nosso continente, Guimarães Rosa faz emergir, em sua obra literária, um fato estético novo. Ao desvelar a máscara atrás da qual se escondem os rastros de uma história recalcada em quase 500 anos de colonização, as novelas "Cara-de-Bronze" e "O recado do morro" materializam o resultado da bem sucedida operação mediante a qual o escritor mineiro performatiza a inserção de tradição cultural brasileira e latino-americana na modernidade.

\section{Abstract}

The novels "Cara-de-Bronze" and "O recado do morro" are the final product of Guimarães Rosa's work to introduce the Brazilian and Latin-Amercan cultural tradition into Modernism. 